\title{
THE EFFECT OF SUBCONJUNCTIVAL BEVACIZUMAB ON ANGIOGENESIS IN RABBIT MODEL
}

\author{
Nurwasis $^{1,2}$, Diana Yuliawati ${ }^{1}$, Evelyn Komaratih $^{1}$, Heriyawati $^{3}$ \\ ${ }^{1}$ Department of Ophthalmology, Faculty of Medicine, Universitas Airlangga, ${ }^{2}$ Dr. Soetomo General Hospital, \\ ${ }^{3}$ Department of Anatomical Pathology, Faculty of Medicine, Universitas Airlangga, Surabaya, Indonesia
}

\section{ABSTRACT}

\begin{abstract}
The wound healing process is major cause of glaucoma surgery failure and enhances the incapability of controlling the IOP. This aim of study was to evaluate the angiogenesis effect of Bevacizumab injection on the amount and density of blood vessels in the rabbit model after trabeculectomy. It was a true experimental study using 16 eyes of 16 New Zealand White Rabbit (Oryctolagus cuniculus) that divided into two groups. The control group was treated with $0.05 \mathrm{ml}$ of Balanced Saline Solution (BSS). The experimental group was treated with subconjunctival injection of $1.25 \mathrm{mg}$ Bevacizumab in 0.05 BSS. All rabbit was sacrificed, and the eye was enucleated. Thus, the bleb area was dissected after 14 days. Histopathological analysis was performed to evaluate the amount and density of blood vessels. The mean amount of blood vessels in the control group was $22.63 \pm 11.02$, and the experimental group was $14,75 \pm 4.92(p=0.043)$. The mean of blood vessel density in the control group was $19.10 \pm 1.69 \%$, and the experimental group was $16.53 \pm 2.90 \%(p=0.029) \%$. There was a statistically significant difference between the two groups $(p<0.05)$. Subconjunctival bevacizumab in the rabbit model reduces the amount and density of blood vessels compared with subconjunctival BSS injection.
\end{abstract}

Keywords: Angiogenesis; bevacizumab; amount of blood vessel; density of blood vessel; trabeculectomy

\section{ABSTRAK}

Proses penyembuhan luka adalah penyebab utama kegagalan operasi glaukoma dan meningkatkan ketidakmampuan mengendalikan TIO. Tujuan penelitian ini adalah untuk mengevaluasi efek angiogenesis injeksi Bevacizumab pada jumlah dan kepadatan pembuluh darah pada model kelinci setelah trabeculectomy. Itu adalah penelitian eksperimental yang benar menggunakan 16 mata dari 16 Kelinci Putih Selandia Baru (Oryctolagus cuniculus) yang dibagi menjadi dua kelompok. Kelompok kontrol diobati dengan 0,05 ml Solusi Saldo Seimbang (BSS). Kelompok eksperimen diobati dengan injeksi subkonjungtiva 1,25 mg Bevacizumab pada 0,05 BSS. Semua kelinci dikorbankan, dan mata diberi enukleasi. Dengan demikian, daerah bleb dibedah setelah 14 hari. Analisis histopatologis dilakukan untuk mengevaluasi jumlah dan kepadatan pembuluh darah. Jumlah rata-rata pembuluh darah pada kelompok kontrol adalah 22,63 $\pm 11,02$, dan kelompok eksperimen adalah 14,75 $\pm 4,92(p=0,043)$. Rerata kepadatan pembuluh darah pada kelompok kontrol adalah 19,10 $\pm 1,69 \%$, dan kelompok eksperimen adalah 16,53 $\pm 2,90 \%(p=0,029) \%$. Ada perbedaan yang signifikan secara statistik antara kedua kelompok $(p<0,05)$. Bevacizumab subconjunctival pada model kelinci mengurangi jumlah dan kepadatan pembuluh darah dibandingkan dengan injeksi BSS subconjunctival.

Kata kunci: Angiogenesis; bevacizumab; jumlah pembuluh darah; kepadatan pembuluh darah; trabekulektomi

Correspondence: Nurwasis, Department of Ophthalmology, Faculty of Medicine, Universitas Airlangga, Dr. Soetomo Hospital, Jln. Prof dr Moestopo 6-8, Surabaya 60286, Indonesia. E-mail: nurwasisspm@ yahoo.com

pISSN:2355-8393 • eISSN: 2599-056x • doi: http://dx.doi.org/10.20473/fmi.v55i4.17326

- Fol Med Indones. 2019;55:290-294 • Received 24 Sep 2019 • Accepted 28 Nov 2019

- Open access under CC-BY-NC-SA license • Available at https://e-journal.unair.ac.id/FMI/

\section{INTRODUCTION}

Glaucoma is a severe threat to human vision health in the world. It is characterized by glaucomatous optic neuropathy and occurs an increase of intraocular pressure (IOP) (Cioffi et al 2015, Stamper et al 2009). World Health Organization (WHO) in 2002 reported that glaucoma was the second cause of blindness with a prevalence of 4.4 million (around $12.3 \%$ of total blindness in the world). The number of blindness due to glaucoma is expected to increase to 11.4 million in 2020. Furthermore, the prevalence of glaucoma is also expected to increase, from 60.5 million (2010) to 79.6 million (2020) (Quigley \& Broman, 2006). The prevalence of glaucoma in Indonesia was $4.6 \%$. According to a survey at West Java Province showed that the prevalence of glaucoma was $1.2 \%$ for the group above 40 years. In addition, the prevalence of blindness 
due to glaucoma was $0.1 \%$ of the total blindness in 2005 (Riskesdas, 2008).

Trabeculectomy is a surgical procedure most commonly used in glaucoma that is not controlled with drugs. This technique decreases intraocular pressure by creating an artificial duct as a way to discharge aquos from the anterior chamber to the subconjunctival space. The success of trabeculectomy is hampered by the formation of postoperative fibrotic tissue, which causes bleb failure. The success rate of trabeculectomy surgery is quite low. It is caused by the malfunctioning of the bleb due to fibrosis (Mietz 2004, Sheha 2011). Various attempts have been developed to prevent fibrosis, ranging from modification of surgical techniques to perioperative medicament since Skuta and Parrish (1987) revealed the leading causes of trabeculectomy failure due to subconjunctival fibrosis. Until now, there have been no adequate and safe preparations to prevent fibrosis without complications.

In 1983, Chen introduced the first use of antimetabolites such as Mitomycin C (MMC) and 5-Fluorouracil (5-FU) to prevent the formation of postoperative fibrotic tissue. Since then, the procedure for the use of antimetabolites is gaining in popularity and is widely used as an additional procedure in trabeculectomy surgery, especially in patients with high-risk factors for postoperative fibrosis. The use of antimetabolites has side effects, although antimetabolite preparations have been used widely. The mechanism of action of nonspecific antimetabolites triggers complications that threaten vision, including severe postoperative hypotension, bleb leakage, and endophthalmitis. These risk factors give rise to the need for other alternatives in the prevention of postoperative fibrosis trabeculectomy (Lama \& Fetchner 2003, Memarzadeh et al 2009, Sheha 2011).

Vascular Endothelial Growth Factor (VEGF) is one of the growth factors. It has an important role in the wound healing process, among others, in stimulating the process of angiogenesis or the formation of new blood vessels needed for the formation process of postoperative granulation/fibrosis tissue. The use of anti-VEGF is continually growing. Anti-VEGF in ophthalmology was first used in abnormalities in the posterior segment, such as Age-related Macular Edema (AMD), neovascular glaucoma, diabetic retinopathy, and central retinal venous obstruction. Several clinical studies have proven that anti-VEGF administration, such as bevacizumab, can be used to inhibit the wound healing process through inhibition of angiogenesis. Bevacizumab was an effective way of trabeculectomy concerning the complete success rate, IOP, and antiglaucoma medications reduction (Xiaoyan et al 2016).

\section{MATERIALS AND METHODS}

This study was a true in vivo laboratory experimental study with randomized post-test only control group design. It was conducted from August-September 2018 at the Stem Cell Research and Development Center, Airlangga University, Surabaya, Indonesia. Ethics approval for the study was obtained from the Ethics Commission for Basic Science and Clinical Research at the Faculty of Veterinary Medicine, Airlangga University, Surabaya, Indonesia.

\section{Intervention}

Sixteen eyes of sixteen New Zealand rabbits (Oryctolagus cuniculus) were studied. All rabbits were healthy males, weighing between $2.5-3.5 \mathrm{~kg}$ and were four to six months old. The rabbits were divided randomly into a control group (Group 1) $(n=8)$ and an experimental group (Group 2) $(n=8)$. Control group animals received a subconjunctival injection of $0.05 \mathrm{~mL}$ Balanced Saline Solution (BSS), whereas the experimental group received a subconjunctival injection of $1.25 \mathrm{mg}$ of Bevacizumab in $0.05 \mathrm{BSS}$. Bevacizumab is a humanized monoclonal antibody against vascular endothelial growth factor A (VEGF-A) and useful to reduces angiogenesis (Valerie \& Anup 2019). All treatment was conducted during 14 days after trabeculectomy. All rabbit was sacrificed and enucleation. Thus, the eyeballs were placed in a $10 \%$ formalin buffer solution, and conjunctival tissue in the bleb area was cut. The amount and density of blood vessels were evaluated by Hematoxylin-eosin and microscopic evaluation.

\section{Statistical analysis}

The independent T-test was conducted to validate the amount of blood vessels in the New Zealand rabbits model, whereas the density of blood vessels in New Zealand rabbits was evaluated using Wilcoxon - Mann Whitney test. The p-value less than 0.05 (typically = 0.05 ) was considered statistically significant.

\section{RESULTS}

\section{Blood vessel in New Zealand rabbits model}

The initial study was conducted to determine whether Bevacizumab injection affects the amount of blood vessels. It was conducted by Haematokxilin-Eosin and measured the amount average of blood vessel in the trabeculectomy area. Table 1 shows the mean amount of blood vessels in the eye of New Zealand rabbits model. 
Table 1. The mean amount of blood vessels in New Zealand Rabbits

\begin{tabular}{ccc}
\hline Groups & Mean (SD) & P1-tailed \\
\hline Balanced Salt & 22.63 & $0.043^{*}$ \\
Solution (BSS) & $(11.02)$ & \\
Bevacizumab & $14.74(4.92)$ & \\
\hline *Note: significant at $\alpha=0.05(\mathrm{p}<0.05)$ &
\end{tabular}

The mean amount of blood vessels was $22.63 \pm 11.02$ in the control group (BSS). The mean number of blood vessels was $14.74 \pm 4.92$ in the experimental group (Bevacizumab). The mean difference in blood vessel number between groups was tested by the independent t-test (Table 1). The mean amount of blood vessels in the experimental group was less than in the control group ( $\mathrm{p}<0.05)$ according to independent T-test.

\section{Vascular density in New Zealand rabbits model}

The evaluation of blood vessel density in control and experimental groups is shown in Table 2. It was conducted by Haematokxilin-Eosin and measured the density of blood vessels in the trabeculectomy area.

Table 2. The mean of blood vessel density in New Zealand Rabbits

\begin{tabular}{lcc}
\hline \multicolumn{1}{c}{ Group } & $\begin{array}{c}\text { Avarage } \% \\
(\mathrm{SD})\end{array}$ & P1-tailed \\
\hline Balanced Salt & 19.10 & $0.029 *$ \\
Solution & $(1.69)$ & \\
(BSS) & 16.53 & \\
Bevacizumab & $(2.90)$ & \\
*Note: significant at $\alpha=0.05(\mathrm{p}<0.05)$ &
\end{tabular}

Table 2 shows that the mean density of blood vessels was $19.10 \pm 1.69 \%$ in the control group. The mean density of blood vessels was $16.53 \pm 2.90 \%$ in the study group. The blood vessel density in the treatment group was lower than in the control group ( $p<0.05)$, according to the Wilcoxon-Mann Whitney test.

\section{Microscopic evaluation of blood vessel}

The blood vessel of conjunctiva tissue in the eyes of New Zealand Rabbits Model was demonstrated in Fig. 1 between the control group and the experimental group. The arrow sign shows the blood vessel.

\section{DISCUSSION}

The failure of trabeculectomy is primary due to fibrosis and scar formation of subconjunctival tissue around the scleral flap and bleb during the wound-healing process. Bevacizumab is a humanized nonselective monoclonal antibody against vascular endothelial growth factor (VEGF). Bevacizumab has important role in inhibiting scar formation and fibrosis through the inhibition of angiogenesis information. Previous studies found that the VEGF levels were elevated in patients who had a trabeculectomy. Furthermore, the concentration of VEGF was significantly reduced after the application of bevacizumab and may have the potential to work in trabeculectomy (Xiaoyan et al 2014).

In a present study, we evaluated angiogenesis parameters of the amount and density of blood vessels between the control and the experimental group. The mean amount of blood vessels was $22.63 \pm 11.02$, whereas the blood vessel density was $19.10 \pm 1.69 \%$ in the control group. In addition, the mean amount of blood vessels was $14.75 \pm 4.92$, whereas the blood vessel density was $16.53 \pm 2.90 \%$ in the study group. These statistical data showed that the differences between the two groups. We found that the amount and density of blood vessels were less in the experimental group that received bevacizumab injections when compared with control groups (BSS injections).

Some studies have been reported that bevacizumab effects in modulating wound healing after trabeculectomy. The study was conducted in vivo using 48 eyeballs of New Zealand rabbits and divided into 4 groups. Group 1 was injected with BSS $0.1 \mathrm{ml}$, group 2 was injected with bevacizumab $0.1 \mathrm{mg}(1.25 \mathrm{mg})$ on the bleb, group 3 with intravitreal bevacizumab, and group 4 with 5-fluorouracil subconjunctival. IOP evaluation, bleb size, bleb height, and bleb vascularity were performed. The right eye of 2 rabbits in each group was enucleated on days 10,20 , and 30 for histopathological evaluation. The results showed that the length, width, and height of the bleb in group 2 were higher among the other group. In addition, the mean IOP was lower in group 2. Histopathological evaluation showed that inflammation, neovascularization, and fibrosis were lower in group 2. Subconjunctival injection of bevacizumab was also found to be more effective compared to intravitreal injection or subconjunctival 5FU injection in maintaining the bleb (Ozgonul et al 2014). 
A.

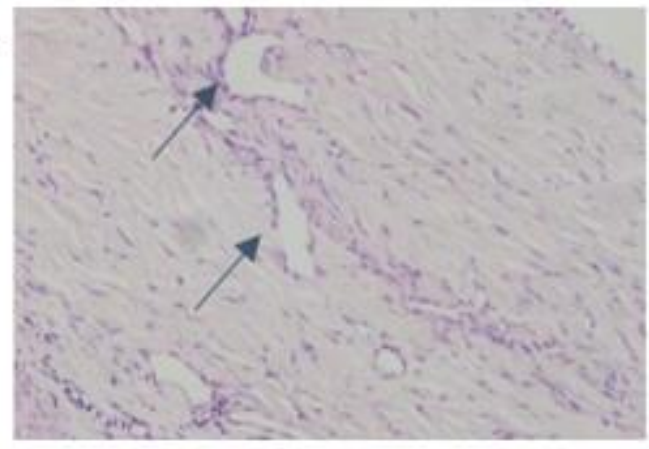

B.

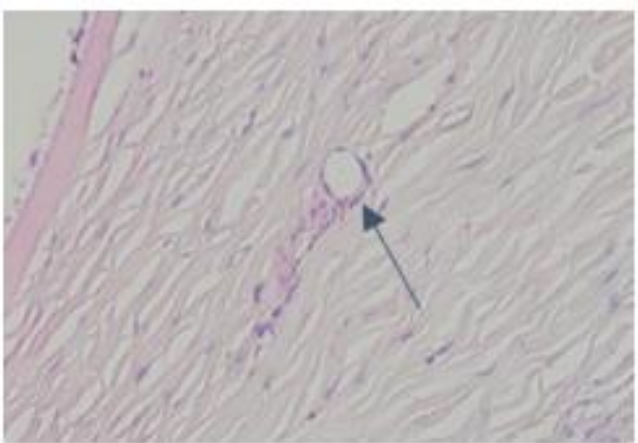

Fig. 1. Conjunctiva tissue in eyes of New Zealand Rabbits Model with Haematoxylin Eosin (HE). A: control group; B: experimental group (Nikon H600L, magnification 400x).

The administration of bevacizumab in glaucoma filtration surgery was found a significant reduction of angiogenesis and collagen deposition. Therefore, the success of glaucoma surgery could be increased. This study used 34 rabbits that were operated on in both eyes. Immediately after surgery, the left eye was injected with $25 \mathrm{mg} / \mathrm{ml}$ bevacizumab, and the right eye as control was injected with $0.9 \% \mathrm{NaCl}$. Histopathological examination was performed to assess blood vessel density by calculating positive areas on CD-31. The results showed significantly lower the density of blood vessels in the study group compared to the control group (Li et al 2009). A study of 26 New Zealand rabbits with bevacizumab, 5-FU, phosphate buffer saline (PBS), the combination of Bevacizumab and 5FU group. This study revealed a significant decrease in the conjunctival vascularization injected with bevacizumab, both in Bevacizumab group and Bevacizumab and 5-FU combination group (How et al 2010).

\section{CONCLUSION}

Bevacizumab injection affected against angiogenesis parameters of the amount and density of blood vessels in the New Zealand White Rabbit model. The amount and density of blood vessels in the experimental group that received bevacizumab injection was lower than in the control group that received BSS injection. It indicated that the administration of bevacizumab in trabeculectomy surgery reduced the number and density of blood vessels in the wound healing process and prevented subconjunctival fibrosis.

\section{ACKNOWLEDGMENT}

Authors sincerely thank to the Stem Cell Research and Development Center and Anatomical Pathology
Department, Faculty of Medicine, Universitas Airlangga, Surabaya, Indonesia that kindly helped in obtaining and collecting our data.

\section{REFERENCES}

Cioffi GA, Durcan FJ, Girkin CA, Gupta, N PiltzSeymour JR, Samuelson TW (2015). Basic and clinical science course: Glaucoma. San Fransisco, American Academy of Ophthalmology

How A, Chua JL, Charlton A, Su R, Lim M, Kumar RS, Crowston JG, Wong TT (2010). Combined treatment with bevacizumab and s-fluorouracil attenuates the postoperative scarring response after experimental glaucoma filtration surgery. Invest Ophthalmol Vis Sci 51, 928-932

Lama PJ, Fechner RD (2003). Antifibrotics and Wound Healing in Glaucoma Surgery. Surv Ophthalmol 48, 314-346

Li Z, Bergen TV, Veire SV, Vel IV, Moreau H, Dewerchin M, Maudgal PC, Zeyen T, Spileers, W, Moons L, Stalmans I (2009). Inhibition of Vascular Endothelial Growth Factor Reduces Scar Formation after Glaucoma Filtration Surgery. Investigative Ophthalmology \& Visual Science 50, 5217-5225

Memarzadeh F, Varma R, Lin LT, Parikh JG, Dustin L, Alcaraz A, Eliott D (2009). Postoperative Use of Bevacizumab as an Antifibrotic Agent in Glaucoma Filtration Surgery in the Rabbit. Invest Ophthalmol Vis Sci 50, 3233-37

Mietz H (2004). Wound Modulation in Glaucoma Surgery dalam Ghren, F. \& Stamper, R. (Eds.). Essential in Ophthalmology: Glaucoma. Berlin, Springer-Verlag

Ozgonul C, Mumcuoglu T, Gunal A (2014). The effect of bevacizumab on wound healing modulation in an experimental trabeculectomy model. Current Eye Research 39, 451-459 
Quigley H, Broman AT (2006). The number of people with glaucoma worldwide in 2010 and 2020. Br J Ophthalmology 90, 262-267

Sheha, H. (2011). Update on modulating wound healing in trabeculectomy. In S Rumelt (Ed.). Glaucoma-Basic and Clinical Concept.Intech. Available at http:// www.intechopen.com/books/glaucoma-basic-andclinical-concepts/update-on modulating-woundhealing- in-trabeculectomy. Accessed July 9, 2019.

Skuta GL, Parrish RK (1987). Wound healing in glaucoma filtration surgery. Surv of Ophthalmology 32, 149-70
Stamper RL, Lieberman MF, Drake MV (2009). Introduction and classification of the glaucomas dalam RL Stamper, MF Lieberman, MV Drake (Eds.). Becker-Schaeffer's Diagnosis and Therapy of the Glaucomas (8th Ed.). UK, Mosby Elsevier

Valerie Gerriets, Anup Kasi (2019). Bevacizumab. USA, StatPearls Publishing LLC.

Xiaoyan Liu, MM Liang Du PhD, Ni Li MD (2016). The effects of bevacizumab in augmenting trabeculectomy for glaucoma: A systematic review and meta-analysis of randomized controlled trials. Medicine 95, 15 